\title{
Ballonos pulmonalis angioplasztika krónikus tromboembóliás pulmonalis hipertóniában
}

\author{
Balogh László, Szűk Tibor, Daragó Andrea, Péter Andrea, Édes István
}

Debreceni Egyetem Klinikai Központ, Kardiológiai és Szívsebészeti Központ, Debrecen

Levelezési cím: Dr. Balogh László, e-mail: laszlobalogh76@yahoo.com

\begin{abstract}
A krónikus tromboembóliás pulmonalis hipertónia (CTEPH) a pulmonalis embóliát (PE) követően alakul ki abban az esetben, ha az embólus(ok) feloldódása inkomplett és azok olyan mértékü mechanikus obstrukciót okoznak, amely a pulmonalis nyomást megemeli. A pulmonalis hipertóniát $(\mathrm{PH})$ két tényező hozza létre. Az egyik a mechanikus obstrukció, a másik pedig a nem obstruált erekben fokozódó áramlás és nyomás miatt bekövetkező arteriopathia és remodelling. PE-t követően 3-6 hónappal fennálló nehézlégzés felveti CTEPH lehetőségét, így echokardiográfia végzése szükségessé válik. Amennyiben a vizsgálat emelkedett pulmonalis nyomást mutat, akkor a további kivizsgálás eszközei a ventilációs-perfúziós tüdőszcintigráfia, Swan-Ganz-katéteres vizsgálat, pulmonalis CT-angiográfia (CTPA) és a pulmonalis angiográfia (PA). Ezen vizsgálatok tükrében láthatóvá válik az embólus elhelyezkedése és eldönthető, hogy pulmonalis endarterecomia (PEA) vagy ballonos pulmonalis angioplasztika (BPA) végezhető. Az esetek közel felében a szervült thrombus sebészileg nem érhető el, így a BPA az egyetlen terápiás alternatíva, mivel a gyógyszeres kezelés CTEPH esetén csak kevésbé hatékony. BPA során a rutin koronária-intervenciókban használt eszközöket: drótokat és ballonokat használjuk, de stentbeültetésre nincs szükség. A beavatkozást több ülésben végezzük. Egy alkalommal csak kis terület revaszkularizációjára kerül sor, hogy elkerüljük a reperfúziós tüdőödémát. Két CTEPH-eset kapcsán mutatjuk be az eljárást, amelyet tudomásunk szerint először alkalmaztunk Magyarországon.
\end{abstract}

Kulcsszavak: ballonos pulmonalis angioplasztika, CTEPH

\section{Balloon Pulmonary Angioplasty Chronic Thromboembolic Pulmonary Hypertension}

Chronic thromboembolic pulmonary hypertension (CTEPH) develops after pulmonary embolism (PE) when resolution of the clot is incomplete resulting in mechanical obstruction, which leads to elevation of the pulmonary pressure. Two factors are responsible for pulmonary hypertension $(\mathrm{PH})$; the first is the mechanical obstruction, the second is the arteriopathy and vascular remodelling due to flow acceleration in non-obstructed vessels. Dyspnea over 3-6 month after $\mathrm{PE}$ raises the suspicion of $\mathrm{CTEPH}$, so echocardiography is indicated in such cases. When echocardiography reveals elevated pulmonary pressure, further investigations are required such as ventilation-perfusion lung scintigraphy, SwanGanz catheterisation, CT pulmonary angiography (CTPA) and pulmonary angiography (PA). According to the results of the above mentioned examinations it can be decided if pulmonary endarterectomy (PEA) or balloon pulmonary angioplasty is necessary to be performed. The organized thrombus cannot be reached surgically in nearly half of the cases, so BPA is the only therapeutic choice while drug treatment is less effective in CTEPH. Wires and balloons used in routine coronary interventions are used during BPA as well, but stent implantation is not required. The procedure is performed in multiple sessions. A small area is revascularised during one session to avoid reperfusion lung oedema. To best of our knowledge we are the first, who performed such cases in Hungary.

Keywords: balloon pulmonary angioplasty, CTEPH 


\section{Definíció és patogenezis}

A krónius tromboembóliás pulmonalis hipertónia (CTEPH) közel 20 évvel ezelött leírt entitás, amely pulmonalis embóliát (PE) követően alakul ki abban az esetben, ha az embólus(ok) feloldódása inkomplett és azok olyan mértékű mechanikus obstrukciót okoznak, amelyek következtében megemelkedik a pulmonalis nyomás (1). PE után az esetek 0,4-9,1\%-ában alakul ki CTEPH (1), az éves incidencia pedig a diagnosztikus hatékonyságtól függően 3-30/millió lakos (2). A pulmonalis hipertóniát (PH) két tényező hozza létre, az egyik a mechanikus obstrukció, a másik pedig a nem obstruált erekben fokozódó áramlás és nyomás miatt bekövetkező arteriopathia és remodelling $(3,4,5)$. Mai napig élénken vizsgált terület, hogy egyes embereknél miért alakul ki CTEPH embóliát követően, míg másoknál nem. Az esetek több mint felében nem mutatható ki coagulopathia a háttérben, viszont a fennmaradó esetekben antifoszfolipid szindróma (20\%), dysfibrinogenaemia (15\%), emelkedett VIII-as faktorszint $(39 \%)$ igazolható $(3,5)$. Megfigyelték továbbá, hogy bizonyos rizikótényezők fokozzák a CTEPH kialakulásának esélyét PE után, ilyenek a splenectomia, ventriculo-atrialis söntök, krónikus gyulladásos (bél)betegségek vagy fertőzött pacemaker-elektróda, hypothyreosis és tiroxinpótlás, valamint malignus (hematológiai) betegségek és a nem 0-ás vércsoport $(6,7)$.

\section{Diagnózis}

A pulmonalis hipertóniát a nemzetközi irodalomban öt csoportra osztják, amelyen belül a CTEPH képviseli a 4. csoportot. A tünetek megjelenéséhez a vaszkulatúra közel felének elzáródása vezet (2). Legfőbb tünetei a fulladás, fáradékonyság, szédülés, syncope, ritkábban hemoptoe. Tüdőembóliát követöen 3-6 hónappal rutinszerüen javasolható echokardiográfia, különösen akkor, ha a beteg dyspnoés, vagy a fenti tünetek közül fennáll valamelyik (8). A betegek $25-63 \%$-ának azonban nincs ismert PE az anamnézisében (7). Gyakori, hogy fulladásos panaszok kapcsán készült echokardiográfia során vetődik fel a diagnózis. Amennyiben az echokardiográfiával mért tricuszpidális regurgitáció sebessége meghaladja a 2,8 $\mathrm{m} / \mathrm{s}$-ot, a pulmonalis szisztolés nyomás (PAPs) tehát $36 \mathrm{Hgmm}$, akkor nagy a valószínüsége, hogy a pulmonalis középnyomás (PAPm) nagyobb, mint $25 \mathrm{Hgmm}$, azaz pulmonalis hipertónia $(\mathrm{PH})$ áll fenn. Súlyos PH (PAPm $>50 \mathrm{Hgmm})$ esetén a kétéves túlélés $20 \%(9)$, tehát igen nagy mortalitású kórképpel állunk szemben. PH esetén, ha a beteg panaszai ezt indokolják, javasolt a CTEPH irányú kivizsgálás. Az echokardiográfia után következő lépésként a ventilációs-perfúziós tüdőszcintigráfia $(\mathrm{V} / \mathrm{Q}$ scan) javasolható, amelynek negativitása kizárja a CTEPH jelenlétét (10). Pozitivitás esetén pulmonalis CT-angiográfia (CTPA) és Swan-Ganz-katéteres vizsgálat javasolt. A
CTPA szenzitivitása azonban csupán $51 \%(2,8)$, amely ugyan 76\%-ra növelhető a szeletszám 320-ra történő fokozásával (11), de még mindig elmarad a pulmonalis angiográfiához képest. Kimondható tehát, hogy az akut pulmonalis embólia esetén észlelt $90 \%$ körüli CTPA diagnosztikus érzékenység jelentősen csökken, ha krónikus embolizáció (CTEPH) jeleit keressük, tehát a CTPA negativitása egyáltalán nem zárja ki a diagnózist. Swan-Ganz-katéterezéssel megerősítjük a diagnózist (direkt módon mérhető a pulmonalis középnyomás - PAPm), illetve felvetheti egyéb társult betegség jelenlétét, amely emeli a pulmonalis nyomást. Fontos továbbá sorra vennünk a legfőbb $\mathrm{PH}$ etiológiai faktorokat, különösképpen kizárni a krónikus tüdőbetegséget (légzésfunkció, diffúziós kapacitás, HR-CT stb. PH 3. csoport) és a balszívfél-betegség okozta magasabb töltőnyomást ( $\mathrm{PH} 2$ 2. csoport). A diagnózis utolsó lépéseként pulmonalis angiográfia szükséges, amely a kórisme gold standardja. A pulmonalis angiográfia nemcsak megerősíti a diagnózist, de lehetőséget is ad a szervült thrombusok lokalizációjában és ezzel együtt a betegség kezelési módjának megválasztásában.

Pulmonalis hipertónia $(\mathrm{PH})$ etiológiai klasszifikációja (12):

-1. típus: pulmonalis artériás hipertónia (PAH),

-2. típus: balszívfél-betegség miatt kialakult $\mathrm{PH}$,

-3. típus: tüdőbetegség/hipoxia okozta $\mathrm{PH}$,

-4. típus: krónikus tromboembóliás PH (CTEPH),

-5. típus: nem tisztázott, illetve multifaktoriális $\mathrm{PH}$.

\section{Kezelés}

Mivel a betegséget mechanikus obstrukció okozza, így a gyógyszeres kezelés jelentősége kicsi, bár a guanilát-cikláz stimulátor riociguát törzskönyvezve van (IIb) az inoperábilis esetekben (9). A betegek $58 \%$-ában a thrombusok a centrális pulmonalis vaszkulatúrában ülnek, sebészileg elérhetők, így alkalom nyílik a CTEPH standard és évtizedek óta bevett terápiájaként elfogadott pulmonalis endarterectomia (PEA) végzésére (4), a fennmaradó $42 \%$-ban viszont a szervült thrombusok lokalizációja perifériás, így azok sebészileg elérhetetlenek, ezek a betegek nem alkalmasak mütétre. PEA után 10-20\%-ban előfordul reziduális pulmonalis hipertónia, mivel centrális és perifériás érintettség egyszerre van jelen $(2,4,7)$. A fenti számokat látva kimondható az, hogy a CTEPH-betegek közel fele nem orvosolható önmagában műtéttel. A ballonos pulmonalis angioplasztika (BPA) az a módszer, amely segítséget nyújthat a pulmonalis vaszkulatúrában disztálisan elhelyezkedő szervült vérrögök esetében. Az eljárást elsőként 1988ban alkalmazták emberen, de az első 18 beteget bemutató tanulmány csak 2001-ben látott napvilágot (13). Ebben a közlésben még nagyszámú szövődményről tesznek említést, és itt figyelték meg az úgynevezett reperfúziós tüdőkárosodás okozta tüdőödémát. 2004-től 
Japánban (Okayama centrum) tökéletesítették az eljárást, amely a szövődmények drasztikus csökkenéséhez vezetett, ami a BPA-t egyre inkább elfogadott terápiás modalitássá tette. Jelenleg a következő esetekben javasolják Ilb indikációval:

1. PEA nem jön szóba (inoperábilis: perifériás lokalizáció vagy társbetegségek miatt).

2. WHO-FC > II (WHO funkcionális osztályozás alapján jelentős tünetek állnak fenn).

3. PAPm $\geq 30 \mathrm{Hgmm}$.

4. PVR (pulmonalis vaszkuláris rezisztencia) $\geq 300$ dyn/ $\mathrm{cm}^{-5}$.

A ballonos pulmonalis angioplasztika során vena femoralis vagy vena jugularis interna felőli behatolásból a jobb szívfélen keresztül közelítjük meg a tágításra alkalmas szervült okkluzív vagy részben rekanalizált thrombusokat. Az eljárás során a koronarográfia, illetve koronária-intervenciónál hagyományosan használt eszközöket: katétereket, drótokat és ballonokat használják. A drótok közül inkább az alacsony (<1 g) tip-load-ú és hidrofil drótokat preferálják, a ballonokat pedig alulméretezik az ér eredeti átmérőjéhez képest, illetve hogy stentbeültetésre nincs szükség, mivel ezen léziók restenosisra nem hajlamosak (10). A koronáriákban észlelt krónikus elzáródások morfológiája nagyban különbözik a pulmonalis artériákban észleltekhez képest. A tüdőerekben található rekanalizált thrombusok sokszor nehezen vehetők észre még angiográfiával is. Morfológiailag négy csoportra osztják a pulmonalis artériákat obstruáló léziókat (10) (1. ábra).

A perifériás elzáródás okozta CTEPH-eseteknél nem ritka, hogy a pulmonalis szegment artériák több mint fele érintett, de ezen artériák egy ülésben történő tágítása súlyos reperfúziós tüdőödémához vezetne, így a beavatkozást több ülésben végzik. A reperfúziós tüdőödéma kialakulásában régebben a hirtelen áramlásfokozódást, manapság viszont a tágítás okozta mechanikus traumát hangsúlyozzák, ez az oka annak, hogy a ballonokat az ér méretéhez képest alulméretezik. Vaszkuláris trauma nemcsak a ballon felfújásakor (5-8 atm, compliant ballon), hanem a drótok és katéterek felvezetésekor is történhet, amelynek során igen könynyű a vékony pulmonalis ereket penetrálni. Ez az oka annak, hogy a másik leggyakoribb szövődmény a vérzés. A tágítás során kis dózisú heparint alkalmazunk, és a pulmonalis hemodinamikai paraméterek (áramlás, PAPm, PVR) függvényében választjuk meg a tágítandó erek számát (13). Minél súlyosabb az eset, annál kevesebb tágítást végzünk az első alkalommal és annál több ülésben végezzük el az összes ér tágítását. Nem a vizuálisan tökéletes eredményre törekszünk, hanem az áramlás óvatos fokozására és ezzel együtt a nyomás- és rezisztenciaértékek fokozatos csökkentésére. A közlemények a pulmonalis endarterectomiához mérhető javulásról tesznek említést. Amellett, hogy ballonos tágítás kapcsán az átlagosan 45 Hgmm-es PAPm 14-21 Hgmm-rel csökken, a PVR 33-65\%-kal lesz alacsonyabb, az életminőség (WHO-FC) és a 6 perces sétateszt is jelentős javulást mutat, valamint a 2 éves túlélés 100\%-ra emelkedik $(10,13,15,16,17$, 18). A javulás egy része nem azonnal, hanem hetekkel a beavatkozást követően figyelhető meg. Egy 2016-os Japán vizsgálat eredményei alapján BPA-t követően (inoperábilis CTEPH-betegeken) a kedvező hemodinamikai változások mellett szignifikánsan javul a CMR-rel vizsgált jobb- és balkamra-funkció, illetve a pulmonalis áramlás (17). A BPA jelenlegi gyakorlatának kiváló áttekintését olvashatjuk Irene Lang és kollégáinak nem-

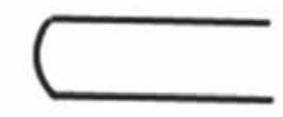

Teljes elzáródás
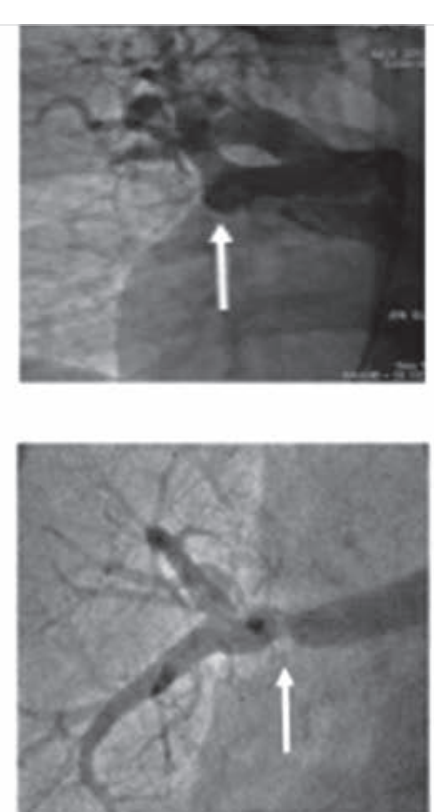

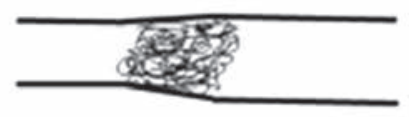

Hálózatos (web) telődés-kiesés

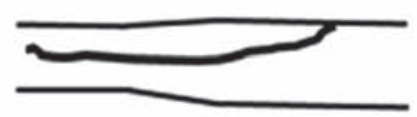

Vonalszerü (slit) telődés-kiesés
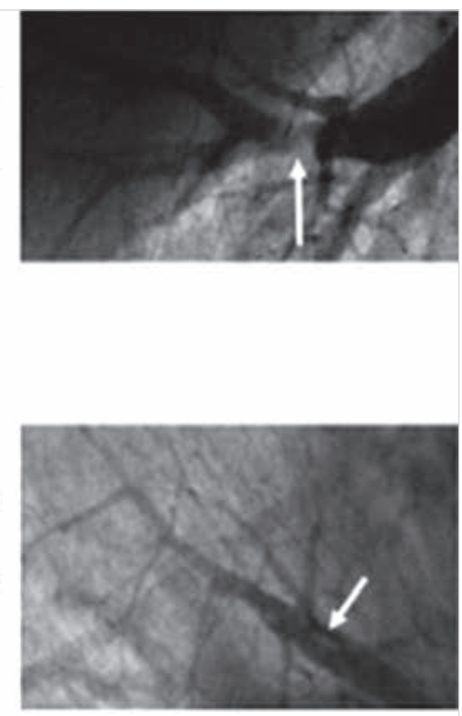

1. ÁBRA. A CTEPH-t okozó szervült thrombusok különböző angiográfiás képet mutathatnak. A rekanalizáció mértékétől függően láthatunk teljes elzáródást és részlegesen rekanalizált artériákat, amelyek hálózatos, gyűrű- vagy vonalszerű telődés- kiesést okozhatnak 
régiben megjelent közleményében (19). A BPA elsajátításához a nemzetközi irodalom 50 beavatkozást tart szükségesnek, amelyet követően az illető azt önállóan is végezheti. Az intervenciót nagy volumenü $\mathrm{PH}$-centrumokban (havi $\geq 2$ új $\mathrm{PAH}, \mathrm{CTEPH}$-eset, havi $\geq 50$ gondozott PH-beteg) javasolják bevezetni, mivel az alacsony éves CTEPH-prevalencia mellett csak itt tudnak megfelelő BPA tapasztalatra szert tenni.

\section{Esetbemutatás}

\section{1. eset}

59 éves férfi betegünk anamnézisében 7 évvel ezelőtt pulmonalis embólia szerepel, amelyet CT-angiográfia is megerősített. A beteg Leiden-heterozigóta, de egyébként a családi anamnézise tromboembólia irányában negatív, és más nagyobb betegsége sem volt korábban. Egy évvel ezelőtt visszatérő tüdőembóliája volt.
Az ezt követően készített echokardiográfia szisztolo-diasztolés D-jelet és 113 Hgmm-es pulmonalis szisztolés nyomást mutatott, az utóbbit a jobbszívfél-katéterezés meg is erősítette (PAPm: $70 \mathrm{Hgmm}, \mathrm{PVR}: 1577$ DS/cm5, PCWP: 14 Hgmm, Cl: 1,6 l/min/m²). A V/Q szcintigráfia mindkét oldalon több szegmentumot érintő perfúziós kiesést jelzett normál ventiláció mellett. A pulmonalis angiográfia számos szegmentartériát érintő tipikus CTEPH-képét mutatta. A beteg panaszai alapján II-es funkcionális stádiumban volt (WHO-FC). Kivizsgálását követően $20 \mathrm{mg}$ rivaroxaban, $5 \mathrm{mg}$ amlodipin és $3 \times 20$ mg sildenafil terápiával engedtük otthonába, majd bécsi Allgemeines Krankenhaus felé referáltuk, akik ballonos pulmonalis angioplasztikára alkalmasnak találták. A beavatkozás során a jobb oldali A9 szegmentartéria proximális rekanalizált thrombusának tágítására, illetve az elzárt A10-es szegmentartéria rekanalizációjára került sor (2. ábra). A beteg a beavatkozást jól tolerálta,
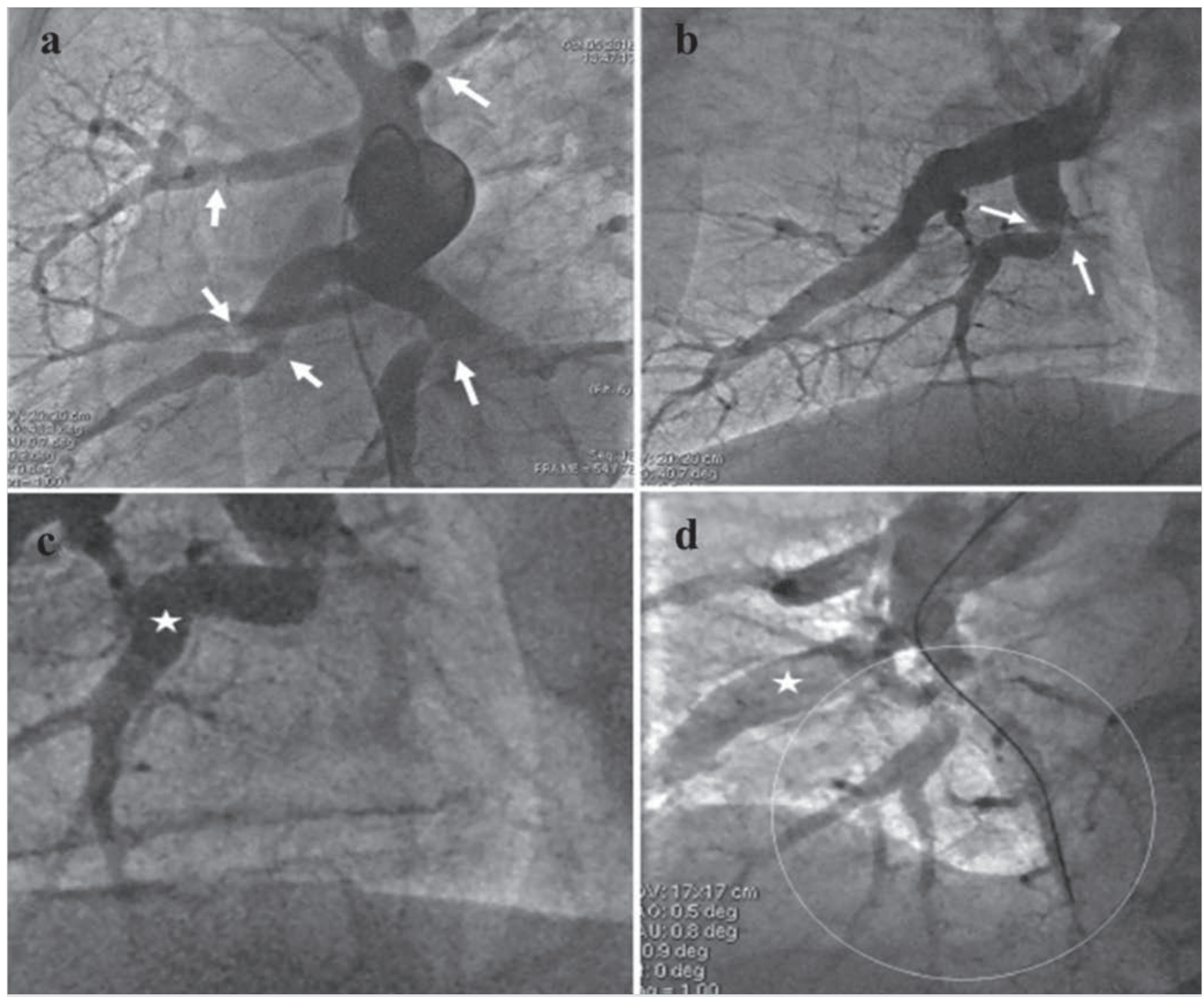

2. ÁBRA. Tipikus perifériás okklúziós típusú CTEPH-angiográfiás képét láthatjuk. a: A nyilak a trombotikus elzáródásokat és telődés-kieséseket mutatják. b és c: nagyított képeken látjuk a jobb oldali A9 (csillag jelöli) és A10-es szegmentum részlegesen rekanalizált és teljes trombotikus okklúzióját. d: A beavatkozás után látható, hogy az A10-es szegmentum artériái megnyíltak 

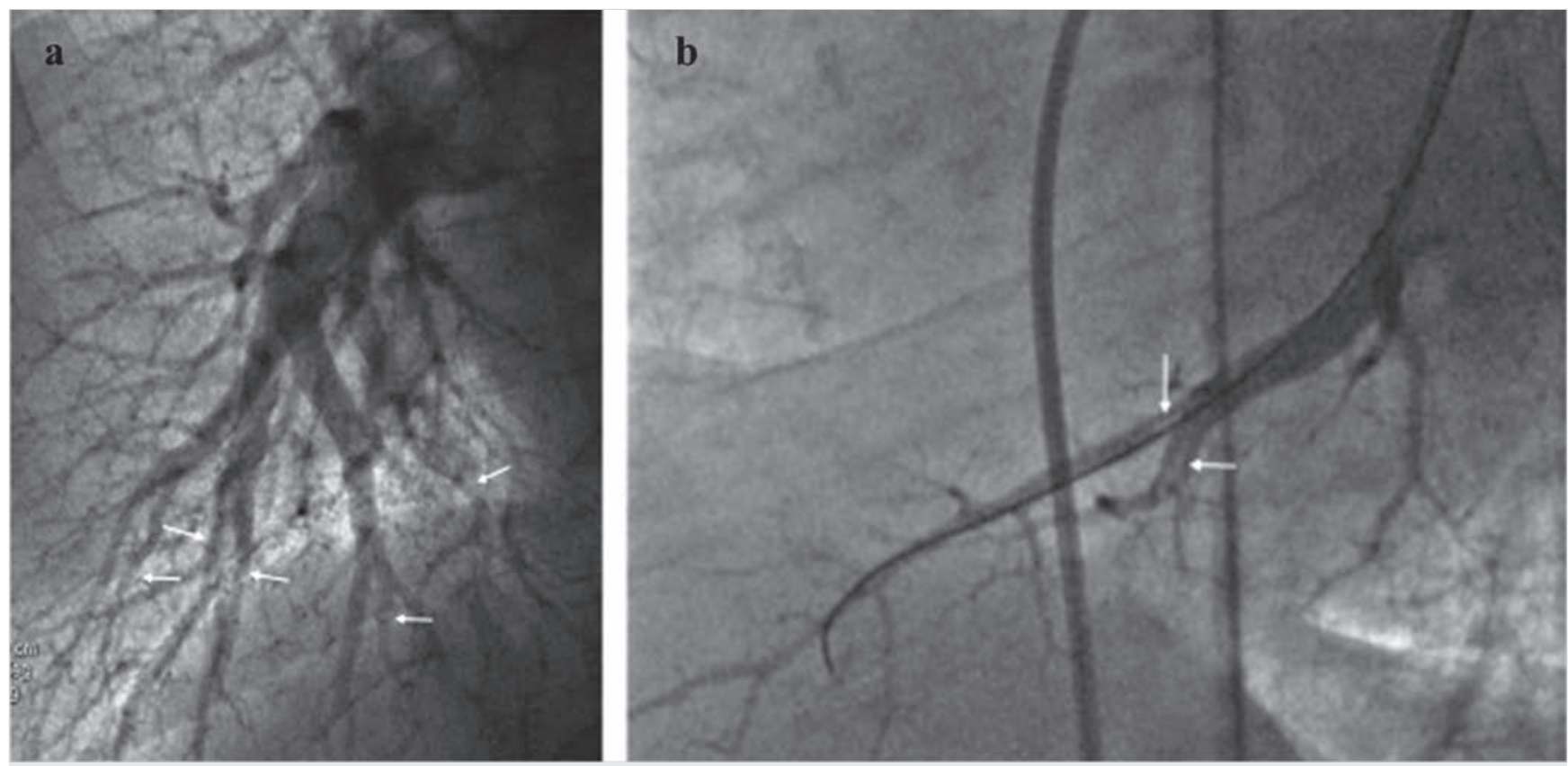

3. ÁBRA. a: A jobb oldali alsó lebeny tipikus perifériás (néhol szubszegmentális) rekanalizált trombotikus lézióit jelölik a nyilak. b:

A tágítást követően is láthatóak a vonalszerű trombotikus eltérések, de az áramlási akadály csökken

periprocedurálisan, illetve a további 48 órában szövődményt nem észleltünk. 1-2 hónap múlva a többi szegmentum tágításával tervezzük folytatni, és ekkor ítéljük majd meg a hemodinamikai javulást Swan-Ganz-katéterezés segítségével. A beteget megfelelő evidencia hiányában NOAC-ról warfarinra állítva bocsájtottuk otthonába.

\section{2. eset}

A 82 éves, egyébként jó állapotú nő anamnézisében 10 évvel ezelőtt koronária stentelés szerepel (a. circumflexa marginalis DES). A beteg hipertóniás és pitvarfibrillál. Tizenöt éve vannak fulladásos panaszai, de tüdőembólia nem szerepel az anamnézisében. Az idén készített echokardiográfia szisztolo-diasztolés D-jelet és emelkedett szisztolés pulmonalis nyomást (77 Hgmm) igazolt, amelyet a Swan-Ganz-katéterezés is megerősített (PAPm: $41 \mathrm{Hgmm}, \mathrm{PVR}: 811 \mathrm{DS} / \mathrm{cm}^{5}$, Cl: 1,92 l/min/m², PCWP: $5 \mathrm{Hgmm}$ ). A koronária stentje vezetett, restenosis nem volt. Érdekes módon a V/Q szcintigráfia nem mutatott $\mathrm{PE}$-re jellemző eltérést, itt a gyanút a CT-angiográfia vetette fel, amelyet a pulmonalis angiográfia is megerősített. Az esetet a bécsi Allgemeines Krankenhaus felé referáltuk, akik ballonos pulmonalis angioplasztikára alkalmasnak találták. A beteg panaszai alapján jelenleg III-as funkcionális stádiumban van (WHO-FC). Elbocsájtásakor $20 \mathrm{mg}$ rivaroxabant, $100 \mathrm{mg}$ aszpirint, $10 \mathrm{mg}$ perindoprilt, 1,25 $\mathrm{mg}$ indapamidot, $5 \mathrm{mg}$ amlodipint, $5 \mathrm{mg}$ bisoprololt és szükség esetén furosemidet javasoltunk. A beavatkozás során a jobb oldali A6, A8, A9 és A10 szegmentartériák rekanalizált thrombusainak tágítására került sor (3. ábra). A beteg a beavatkozást jól tolerálta, köz- ben időnként száraz köhögés és átmeneti oxigénszaturáció-csökkenés volt tapasztalható. A beavatkozást követően 4 órával készült mellkas-röntgenfelvételen a kezelt szegmentumban enyhe infiltráció került leírásra, és ezt követően nehézlégzése is jelentkezett, mely 40 mg furosemid iv. adását követően teljesen megszűnt, a másnapi mellkasröntgen már tiszta tüdőt mutatott és ez követően 48 órával sem észleltünk egyéb szövődményt. 1-2 hónap múlva a többi szegmentum tágításával tervezzük folytatni, és ekkor ítéljük majd meg a hemodinamikai javulást (Swan-Ganz-katéterezés). A beteget megfelelő evidencia hiányában NOAC-ról warfarinra állítva bocsájtottuk otthonába.

\section{Köszönetnyillvánítás}

Ezúton szeretnénk köszönetet mondani prof. dr. Irene Langnak és dr. Christian Gergesnek (Bécs, Allgemeines Krankenhaus), akik a beavatkozások végezték $d r$. Szük Tibor és dr. Balogh László asszisztálása mellett, és akik megosztották velünk értékes tapasztalataik.

\section{Irodalom}

1. Kim NH. Group 4 Pulmonary Hypertension: Chronic Thromboembolic Pulmonary Hypertension: Epidemiology, Pathophysiology, and Treatment. CardiolClin. 2016 Aug; 34(3): 435-41. DOI: 10.1016/j. ccl.2016.04.011. DOI: 10.1016/j.ccl.2016.04.011

2. Jorge E, Baptista R, Calisto J, et al. Optical coherence tomography of the pulmonary arteries: A systematic review. J Cardiol 2016 Jan; 67(1): 6-14. DOI: 10.1016/j.jjcc.2015.09.024. DOI: 10.1016/. jjcc.2015.09.024.

3. Lang IM, Dorfmüller P, Vonk Noordegraaf A. The Pathobiology of Chronic Thromboembolic Pulmonary Hypertension. Ann Am Thorac Soc 2016 Jul; 13(Suppl 3): S215-21. DOI: 10.1513/Anna SATS.201509-620AS. 
4. Ogino $\mathrm{H}$. Recent advances of pulmonary endarterectomy for chronic thromboembolic pulmonary hypertension including Japanese experiences. Gen Thorac Cardiovasc Surg 2014 Jan; 62(1): 9-18.

\section{DOI: 10.1007/s11748-013-0323-4}

5. Morris TA, Marsh JJ, Chiles PG, et al. High prevalence of dysfibrinogenemia among patients with chronic thromboembolic pulmonary hypertension. Blood 2009 Aug 27; 114(9): 1929-36. DO 10.1182/blood-2009-03-208264

6. Pepke-Zaba J. Diagnostic testing to guide the management of chronic thromboembolic pulmonary hypertension: state of the art. Eur Respir Rev 2010 Mar; 19(115): 55-8. DO: 10.1183/ 09059180.00007209 7. Kim NH, Lang IM. Risk factors for chronic thromboembolic pulmonary hypertension. Eur Respir Rev 2012 Mar 1; 21(123): 27-31. DOI $10.1183 / 09059180.00009111$

8. Robbins IM, Pugh ME, Hemnes AR. Update on chronic thromboembolic pulmonary hypertension. Trends Cardiovasc Med 2017 Jan; 27(1): 29-37. DO 10.1016/j.tcm.2016.05.010

9. Hoeper MM. Pharmacological therapy for patients with chronic thromboembolic pulmonary hypertension. Eur Respir Rev 2015 Jun; 24(136): 272-82. DO 10.1183/16000617.00001015

10. Ogawa A, Matsubara H. Balloon Pulmonary Angioplasty: A Treatment Option for Inoperable Patients with Chronic Thromboembolic Pulmonary Hypertension. Front Cardiovasc Med 2015 Feb 17; 2: 4. DO: 10.3389/fcrm. 2015.00004

11. Dong C, Zhou M1, Liu D, et al. Diagnostic accuracy of computed tomography for chronic thromboembolic pulmonary hypertension: a systematic review and meta-analysis. PLoSOne. 2015 Apr 29; 10(4) e0126985. DO 10.1371/journal.pone.0126985

12. (G) Galiè N, Humbert M, Vachiery JL, et al. 2015 ESC/ERS Guidelines for the diagnosis and treatment of pulmonary hypertension: The Joint Task Force for the Diagnosis and Treatment of Pulmonary Hypertension of the European Society of Cardiology (ESC) and the
European Respiratory Society (ERS): Endorsedby: Association for European Paediatric and Congenital Cardiology (AEPC), International Society for Heart and Lung Transplantation (ISHLT). Eur Heart $J$ 2016 Jan 1; 37(1): 67-119. DO: 10.1093/eurheartj/ehv317

13. Feinstein JA, Goldhaber SZ, Lock JE, et al. Balloon pulmonary angioplasty for treatment of chronic thromboembolic pulmonary hypertension. Circulation 2001 Jan 2; 103(1): 10-3. doi.org/10.1161/01 CIR.103.1.10

14. Inami T, Kataoka M, Shimura N, et al. Pulmonary edema predictive scoring index (PEPSI), a new index topredictrisk of reperfusion pulmonary edema and improvement of hemodynamics in percutaneous transluminal pulmonary angioplasty. JACC Cardiovasc Interv. 2013 Jul;6(7):725-36. DOI: 10.1016/i jcin.2013.03.009

15. Yamasaki $\mathrm{Y}$, Nagao $\mathrm{M}$, Abe $\mathrm{K}$ et al. Balloon pulmonary angioplasty improves interventricular dyssynchrony in patients with inoperable chronic thromboembolic pulmonary hypertension: a cardiac MR imaging study. Int J Cardiovasc Imaging 2017 Feb; 33(2): 229-239. DOI: 10.1007/s10554-016-0985-y

16. Ogo T. Balloon pulmonary angioplasty for inoperable chronic thromboembolic pulmonary hypertension. Curr Opin Pulm Med 2015 Sep; 21(5): 425-31. DOI: 10.1097/MCP.0000000000000188

17. Sato H, Ota $\mathrm{H}$, Sugimura $\mathrm{K}$, et al. Balloon Pulmonary Angioplasty Improves Biventricular Functions and Pulmonary Flow in Chronic Thromboembolic Pulmonary Hypertension. Circ J 2016 May 25: 80(6): 1470-7. DOI: 10.1253/circj.CJ-15-1187

18. Fukui S, Ogo T, Morita $Y$, et al. Right ventricular reverse remodelling after balloon pulmonary angioplasty. Eur Respir J. 2014 May; 43(5): 1394-402. DO: 10.1183/09031936.00012914

19. Lang I, Meyer BC, Ogo T, et al. Balloon pulmonary angioplasty in chronic thromboembolic pulmonary hypertension. Eur Respir Rev 2017 Mar 29; 26(143). DOI: 10.1183/16000617.0119-2016.

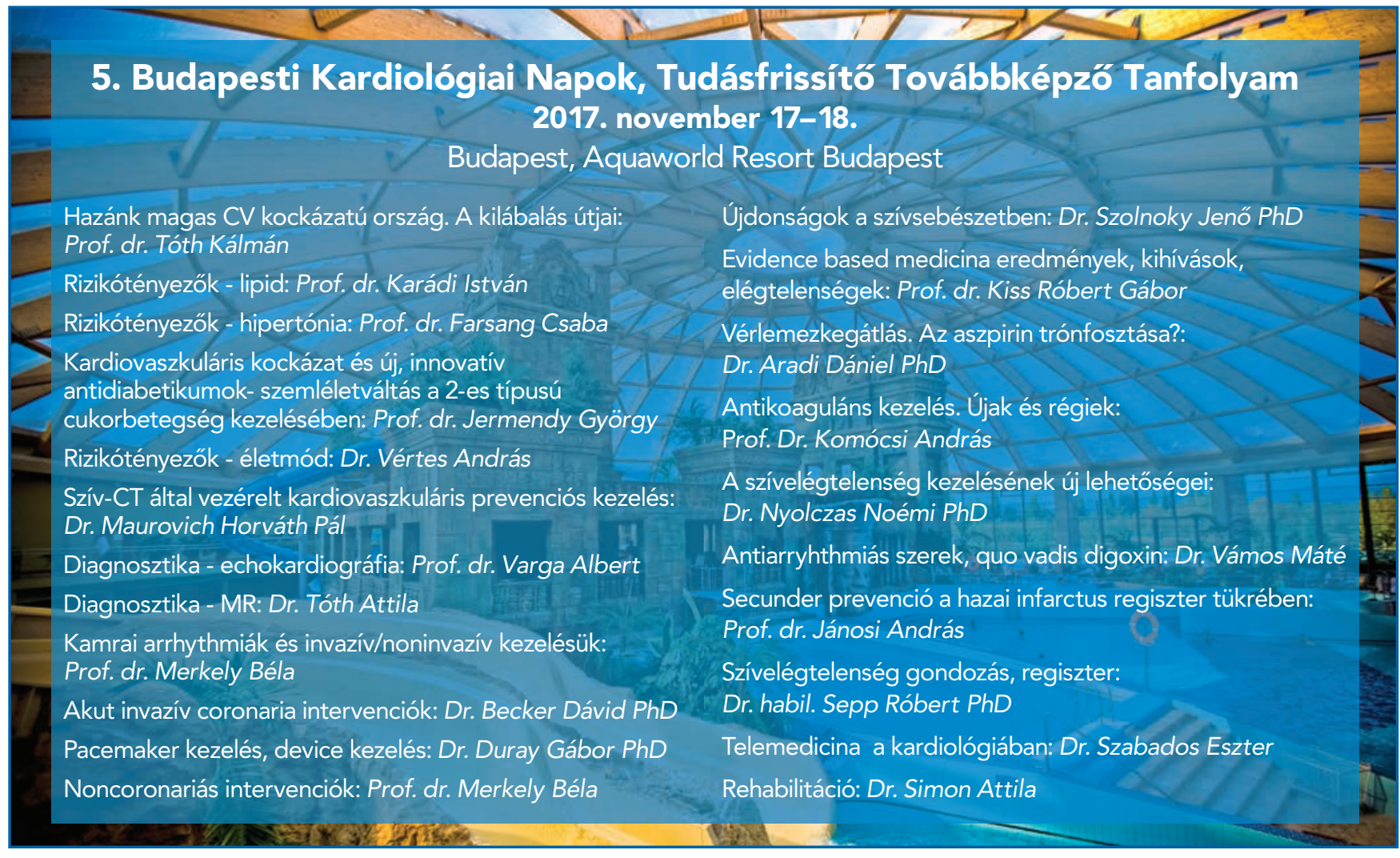

